\title{
ART NOUVEAU: JEWELS AND JEWELERS
}

By Elise B. Misiorowski and Dona M. Dirlam

The Art Nouveau movement, with its startling concepts in design, swept through Europe and the United States in the late 19th and early 20th centuries. The asymmetrical whiplash line which typifies Art Nouveau was manifested in art, architecture, metalwork, textiles, and interior design. Perhaps its most concentrated and refined expression can be seen in the spectacular Art Nouveau jewels, which incorporated more unusual gems and gem materials such as moonstones, hom, ivory, opal, turquoise, and tourmalines into a host of fanciful designs. This article discusses the origins of Art Nouveau and outlines the distinctive interpretations and contributions made by significant Art Nouveau jewelers.

\section{ABOUT THE AUTHORS}

Ms. Misiorowski and Ms. Dirlam are research librarians at the Gemological Institute of America, Santa Monica, California.

Acknowledgments: The authors would like to thank the following people for their invaluable assistance in obtaining illustrations for the article: Vivienne Becker, Robert Crowningshield, François Curiel, Tam Curry, Mary Edgerton, Ralph Esmerian, Fritz Falk, Rila Goodman, John Jesse, Cheryl Kinion, Irina Laski, Eunice Miles, Lillian Nassau, Ira Simon, and Harold and Erica Van Pelt. Ruth Patchick was especially helptul in typing the manuscript.

(c) 1987 Gemological Institute of America
From the mid-19th century to the beginning of the First World War, an enormous surge of creative energy expressed itself in virtually every aspect of Western culture. There were advances in technology and science, and revolutionary expressions in fine art, music, literature, and the applied arts. In this expansive cultural climate, a style was developed that was as unique as it was shortlived. Art Nouveau, as the movement has come to be known overall, grew out of several factors. Technological advances, brought about by the industrial revolution, improved communications internationally through travel and commerce. Exhibitions of exotic arts and artifacts exposed the artists of the day to stimulating new concepts in design and use of materials. These new ideas then added impetus to an artistic revolt against the dehumanizing influences that were also by-products of the industrial revolution.

This new form of expression was manifested differently and given different names in each country, but all were variations of the new art. An early version was called Arts and Crafts, or Liberty Style, in England and later in the U.S. In France it was called Art Nouveau or Fin de Siècle. It was known as Jugendstil in Germany, Secessionstil in Austria, Palingstil in Belgium, and Modernismo in Spain. Although nearly every country in Western culture manifested this new art in some way, not all of them made significant contributions to jewelry design. For example, Italy was so involved in producing replicas of classic jewels that its artisans produced little if any new-art jewelry, although they acknowledged the movement as Stile Liberty. Yet jewelers in England, France, Germany, and the United States played major roles in different developmental stages of the Art Nouveau style. Using more unusual gemstones and materials than their predecessors in the Victorian era or their counterparts in the Edwardian style, the Art Nouveau designers created pieces that are as ex- 
citing and fascinating today as they were when the movement first started more than 100 years ago.

\section{THE ELEMENTS OF ART NOUVEAU}

Origins of the Movement. Many factors influenced the development of Art Nouveau. Of great importance was the desire to break loose from the heavy, ornate, almost repressive styles that held sway during the Victorian period. Innovations in metal technology during the industrial revolution furthered this rigidity of style by enabling the massproduction of machine-made pieces. In the middle of the 19 th century, however, it became fashionable to wear jewelry patterned after ancient Greek, Roman, and Etruscan pieces discovered during the burgeoning of archeology. This historicism gave rise to a romantic revival which saw artists turn away from industry and draw their inspiration directly from nature. In France, interest in the elaborate curved forms of rococo was gradually revived, as a similar revival of interest in the design elements of Gothic and Celtic art was seen in the British Isles. With these revivals came a spiritual yearning for the craft guilds of the Middle Ages. Societies, formed to promote the decorative arts, sponsored exhibits and competitions that acted as further stimuli.

Perhaps the single most important influence on the development of Art Nouveau design, however, was the resumption of trade with Japan in 1854. The exhibits of Japanese art held in the 1860s had a tremendous impact on European artists. When Siegfried Bing (1838-1905) opened a Japanese import shop in Paris in 1871, he further exposed the Parisian artworld to Japanese concepts of design (Weisberg, 1986). The simplicity of Japanese art and the economy of line shown in their interpretation of nature was an immediate inspiration to the Western world. Curve of human form, flow of movement, balanced asymmetry, subtle use of color and shading were aspects of Japanese art that surprised Europe and greatly influenced the manner in which artists viewed and interpreted life forms.

Numerous exhibitions in Europe and the United States displayed artwork and artifacts from many other countries as well, exposing artists to Indian, Arabic, Persian, and Oriental cultures. Exotic species of plants, such as the tiger lily, wisteria, chrysanthemum, bleeding heart, and orchid, often represented in Art Nouveau jewelry, were first introduced to Europe in the 19th cen- tury. Art Nouveau became a metaphor for the metamorphosis of the times, translating the myriad influences into a unique form of art that expressed itself in architecture, fabrics, furniture, wall coverings, and perhaps most pervasively, in jewelry.

Art Nouveau Motifs. Among the many recurring images found in Art Nouveau jewelry, the most widely recognized motif is that of a nalked or partially clothed woman surrounded by her loose flowing hair, often depicted swimming or in flight, symbolically demonstrating her freedom (figure 1). Nature, associated with fertility and femininity, is unselfconsciously sensual. This eroticism is apparent in the sinuous interpretation of nature in the Art Nouveau line, which expressed movement, passion, vitality, and the youthful vigor of new ideas. Often called the "whiplash line," it represents the common element found in virtually every Art Nouveau design and provided the stimulus for some of the descriptive names for Art Nouveau such as Palingstil, which means "eel style."

Winged creatures of many kinds were also common in Art Nouveau jewelry. The peacock in particular is frequently seen, as are swans, swallows, roosters, owls, and bats. Insects such as the dragonfly and butterfly were special favorites because enamelists could skillfully represent the gauzy transparency of wings in a startlingly realistic manner (figure 2). Scarabs, with their mystical connection to Egyptian lore, were also common subjects, as were grasshoppers, bees, and wasps. Snakes, which were often used in Victorian jewels as stiff symbols of eternal love, acquired sinister new life and movement in Art Nouveau (figure 3). The chameleon and lizard were also represented, as were fish, seahorses, and other sea creatures. A "fascination with the shocking and nightmarish,

Figure 1. Partially clad female figures are one of the most common motifs in Art Nouveau jewelry, as illustrated by these two pendants and brooch designed by Spanish jeweler Luis Masriera. The materials used-cast and enameled gold with opals, sapphires, pearls, and plique-à-jour enamel-are also typically Art Nouveau. These pieces are recent remakes from the original mold. The winged piece is $6.0 \times 6.5 \mathrm{~cm}$ long. Courtesy of Rita Goodman, Peacock Alley Collection. Photo (C) Harold $\Theta$ Erica Van Pelt. 


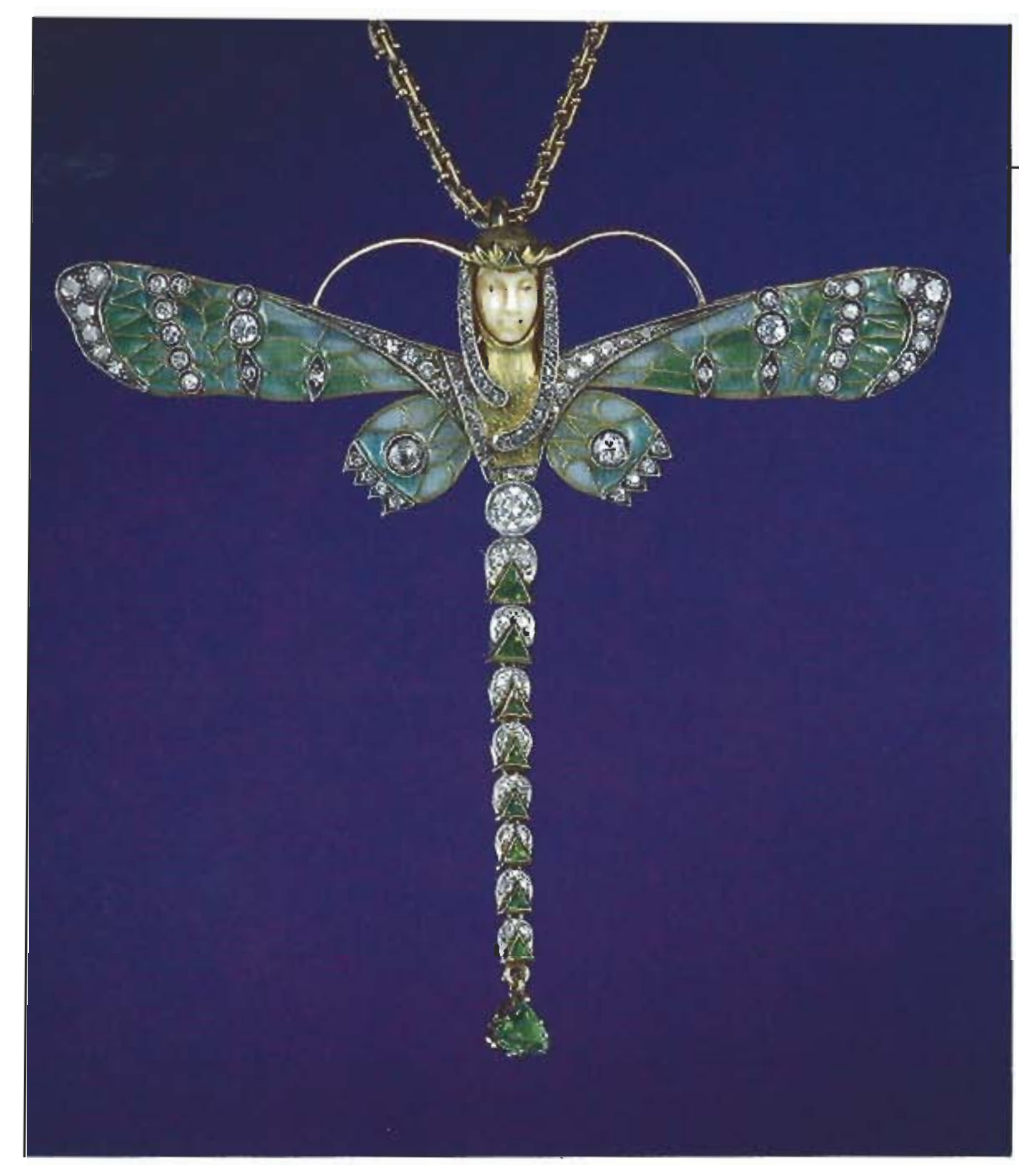

Figure 2. This dragonfly brooch with a woman's face carved in ivory shows one of the fanciful forms that Art Nouveau jewelry often takes. Of gold, ivory, plique-à-jour enamel, diamonds, and demantoid garnets, this piece $(9 \times 8.5 \mathrm{~cm})$ is a recent remake from an original mold by Luis Masriera. Courtesy of Rita Goodman, Peacock Alley Collection. Photo (c) Harold es Erica Van Pelt.

with things which are not what they appear to be" (Becker, 1985) manifested itself as mythical characters and beasts such as Medusas, griffons, dragons, and chimeras.

The Japanese influence can be detected in a realistic view of nature's cycles and elements. Buds or seedpods, full blooms, and withered drooping flowers expressed birth, death, and rebirth, while miniature landscapes depicted the passage of the seasons. These life cycles allowed for a subtle use of color that was typically Art Nouveau: Spring and summer were shown in verdant greens, delicate pinks, mauves, and lavenders, highlighted by rich magentas and purples; deep reds and oranges mixed with subtle earth tones expressed autumn; and the chill of winter can be seen in cool variations of blue and silver.

Gems and Other Materials Used. These colors were best expressed in Art Nouveau jewelry by the extensive use of enamels. This period experienced a renewed interest in enameling, possibly a consequence of the influx of Japanese artifacts which introduced new or forgotten techniques to the West. A variety of enameling techniques came into vogue, including cloisonné, champlevé, plique-àjour, and pâte-de-verre. Cloisonné enamel is made by forming small cells, or cloisons, with wire on a metal backing and filling them with separate colors of enamel. Champlevé enamel involves hollowing out small areas of metal and filling them with enamel. Plique-à-jour is a difficult technique that produces a stained-glass-window effect. Gold chambers backed with thin copper sheets are filled with transparent enamels. After firing, the copper backing is dissolved in an acid bath, leaving the enamel with the transparency of a pane of glass. Pâte-de-verre, the ancient Egyptian technique of melting ground glass and molding it into complex shapes, was reintroduced and often used in place of gem materials.

The combination of inexpensive materials and expensive gems is typically Art Nouveau. There was extensive use of horn and ivory, both of which could be stained soft colors and polished to give them a bloom and sheen. Metals also were given colored patinas to work within the theme of a piece. Gemstones usually were incorporated into the work as accents and complements to the design rather than as the central focus. Opals were popular gems, as their changing colors suggested an inner life. The subtle colors of moonstone, chalcedony, peridot, amethyst, aquamarine, topaz, demantoid garnet, and tourmaline made these gems popular, while diamonds, sapphires, rubies, and emeralds were generally given the secondary role of accents. Mother-of-pearl, turquoise, lapis lazuli, and malachite were often cut en cabochon or used as inlay, while baroque pearls were frequently dangled from pendants and brooches or were used to represent pods or petals.

Some Art Nouveau jewelers continued the ageold practice of incorporating simulants into their jewelry. During this period an imitation emerald triplet was constructed by cementing a rock crystal crown and pavilion with a layer of green gelatin. Called soudé (French for soldered) emeralds, one appears as the center stone in a moth pendant by Lucien Gautrait (figure 4). Also during the 19th century, scientists in national museums and universities were attempting to duplicate gems and minerals by growing synthetics. Auguste Victor 
reputation for taste by indulging herself in the purchase of a piece of contemporary jewelry ..." (Battersby, 1968).

While Art Nouveau was one of the first truly international movements, Art Nouveau jewelry tended to acquire the character of each country in which it was fashioned. Thus, to understand the various manifestations of Art Nouveau jewelry, we will examine some of the foremost designers from those countries in which Art Nouveau had a major impact on jewelry.

\section{GREAT BRITAIN}

Much of Art Nouveau's early development occurred in Great Britain. Not only was England the first country to experience the industrial revolution, but it was also the most advanced industrial nation throughout the 19th century. Furthermore, its dominant role as a colonizing empire brought new ideas and exotic objects which stimulated artistic as well as scientific and political thought. By the early 1800 s, critics were questioning the impact of the industrial revolution on daily life. The Great Exhibition of London in 1851 further strengthened their case. The display of machinemade goods - shoddy and often tasteless - was impetus to the movement. The art community called for a return to the principles of freedom of expression for individual artists and craftsmen. This, they argued, would bring an enjoyment of art to the lives of ordinary people. The Arts and Crafts movement was the expression of this change.

John Ruskin (1819-1900) laid the foundation for the Arts and Crafts movement with his ideas and his writing. In his earliest published work (1843), he tells the artist to "go to Nature in all singleness of heart, and walk with her laboriously and trustingly" (Nevins, 1986).

By the 1850 s, a young undergraduate, William Morris (1834-1896), had joined Ruskin's cause. In 1861, Morris started a firm to produce tapestries, wallpaper, textiles, stained glass, and furniturecalled Morris, Marshall, Faulkner \& Co.-that promoted natural themes. The motifs that Morris used for his wallpapers and fabrics were drawn from simple flowers in his garden: tulips, honeysuckles, lilies, daisies, anemones, marigolds, larkspurs, and carnations (Nevins, 1986).

The Arts and Crafts movement also promoted the formation of guilds and art schools, where craftsmen were trained to design, make, and decorate the object from beginning to end. For the first time, women were also involved in the design and fabrication of jewelry and jeweled objects. Shunning precious metals and expensive gemstones, they used humble materials and enameling to produce strong yet simple pieces.

Although Ruskin established the first cooperative, the Guild of St. George, in 1871, Charles R. Ashbee (1863-1942), a former architect and a selftaught silversmith and jeweler, was the most influential designer of the Arts and Crafts movement. He founded the School of Handicraft in 1888; out of his work, his theories, and his guild evolved guidelines for other groups (Hinks, 1983).

Ashbee is particularly famous for his interpretations of the peacock motif, making use of turquoise-colored enamels or abalone (figure 5). He often set the feathers with gemstones from the expanding British empire: pearls from India, opals from Australia, moonstones from Ceylon (Sri Lanka), and diamonds from South Africa (Armstrong, 1977). These continued to be favorites of the Art Nouveau jewelers. Ashbee's sensuous use of plant motifs, moths, and other insects heralded the onset of Art Nouveau themes.

While the Arts and Crafts movement of the 1880 s was the catalyst for the whole European and American artistic revolution, it was Arthur Lazenby Liberty (1843-1917) who translated its esoteric design into fashionable jewels. After apprenticing as a draper, Liberty joined the Farmer and Rogers' Great Shawl and Cloak Emporium in Regent Street in 1862. This was the very same year of the International Exhibition in Kensington, where the major attraction was the Japanese section. Farmers and Rogers bought the bulk of the Japanese exhibit and opened the Oriental Warehouse, which Liberty managed for many years before he opened his own shop, the East India House.

Liberty saw the talent and potential of the Arts and Crafts designers, and commissioned exclusive designs for his fabrics (figure 6) and later for silver and other metalwork. He began importing Art Nouveau objects from the Continent around 1897, notably some of the Jugendstil metalware from the German firm of Kayser. When this proved successful, he launched his own line of metalwork in the late 1890 s under the trade name Cymric.

An important aspect of the Cymric style of English Art Nouveau jewelry was its revival of Celtic art. The Celts, who had inhabited West Central Europe, invaded the British Isles about 250 


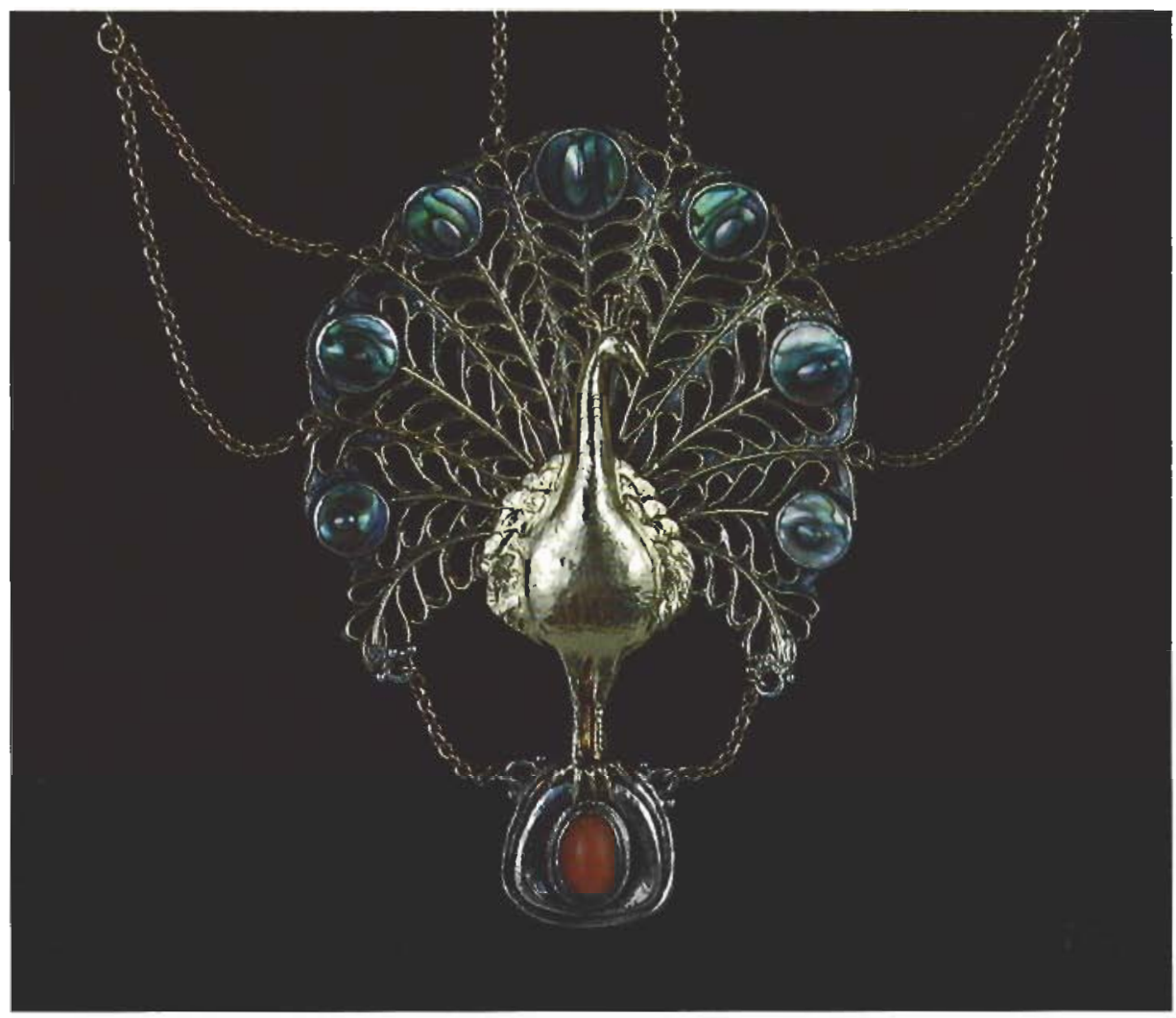

Figure 5. Founder of the Guild of Handicraft in London, Charles Ashbee is known for his use of the peacock motif. This example is of gold, silver, coral, and abalone (c. 1900). Courtesy of the lesse $(t)$ Laski Gallery, London.

B.C. Their art displayed distinctive features of knots, curving lines, and geometric interlacing. Archibald Knox (1864-1933) was largely responsible for the inclusion of Celtic art and the success of the Cymric style (figures 7 and 8).

During this period, the Murrle, Bennett \& Co. jewelry firm produced a distinctive range of jewelry. Some pieces in silver had a hammered finish with tiny bump-like rivets and were often set with mother-of-pearl or amethyst. Also typical were gold jewels with a matte sheen set with turquoise and matrix, opal, amethysts, or baroque pearls. The lines often used the Celtic interlacing or consisted of gold wires draped over a stone.

In Scotland, Charles Rennie Mackintosh (1868-1928), architect and designer, led the Glasgow School, a pioneering group of architects and designers who greatly influenced the decorative arts in Great Britain and America, and in Western Europe. Mackintosh exerted a formative influence on jewelry design in Austria, even though he himself designed only a few pieces of jewelry. His best-known design is one of birds flying through storm clouds with rain drops of pearls.

The Art Nouveau movement in England, though, in the words of author Graham Hughes (1964), "was almost stillborn because of British
Figure 6. This printed cotton (c. 1896) demonstrates how Liberty and Co. adapted the Oriental design elements that had so much influence on the decorative arts during this period. Photograph courtesy of the Smithsonian Institution Traveling Exhibition Service.

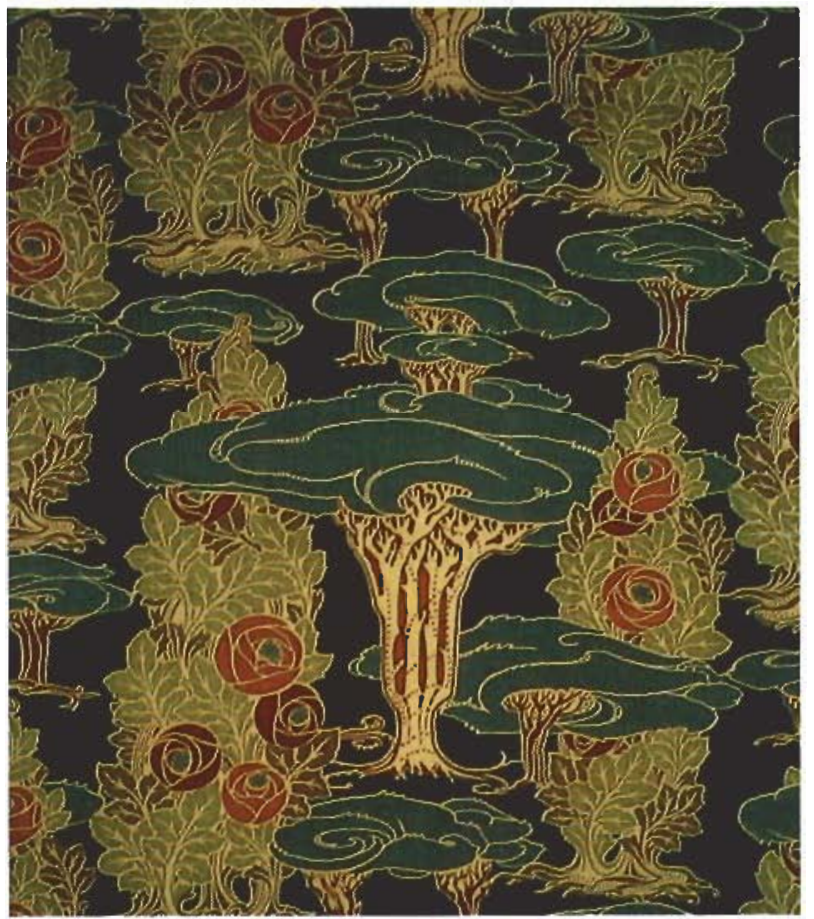




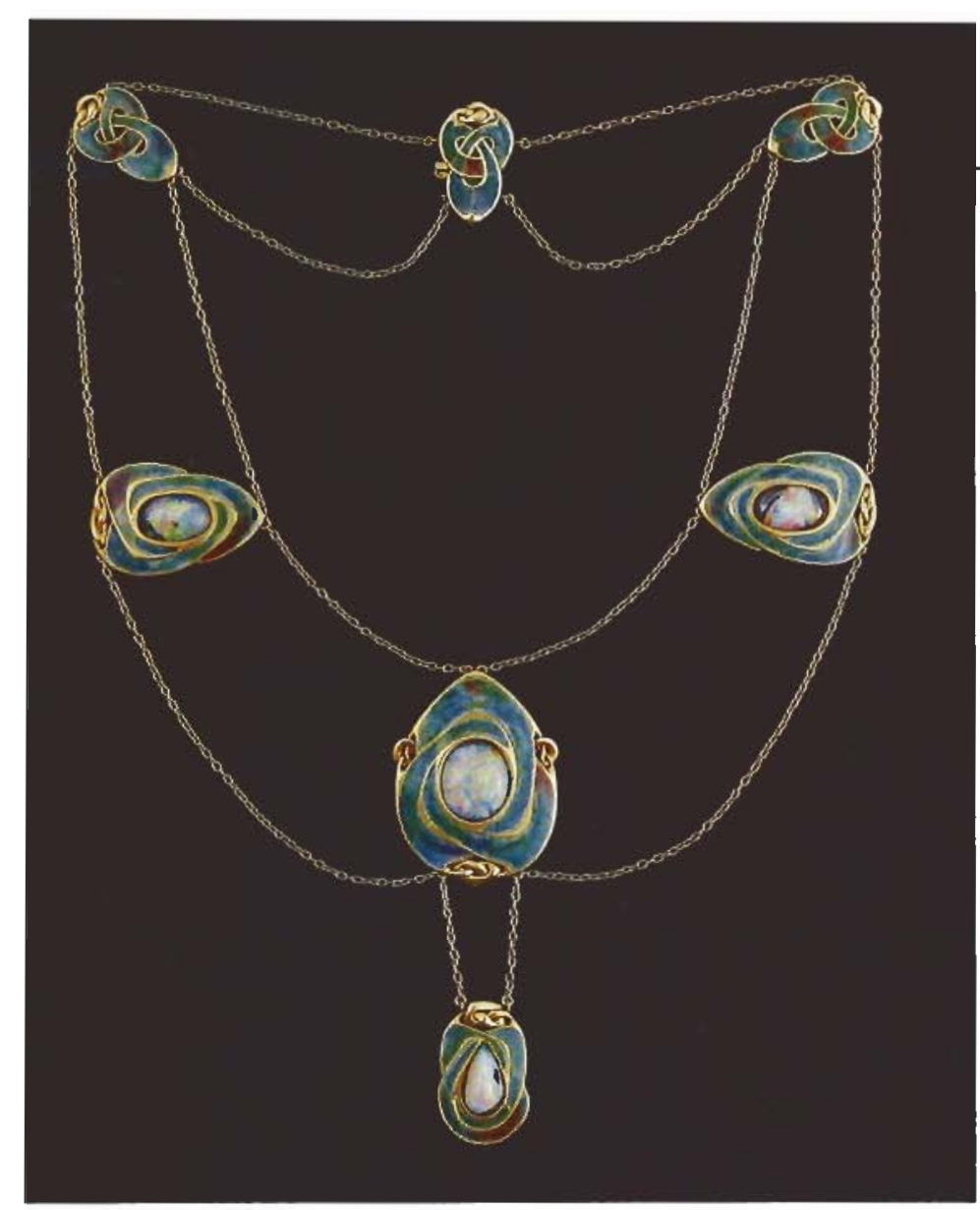

Figure 7. Famed English designer Archibald Knox created this $18 \mathrm{~K}$ gold and opal necklace for Liberty and Company (c. 1900). Courtesy of the Jesse \& Laski Gallery, London.

reticence: as a nation we do not indulge in orgies of visual fun." While the British set the stage in terms of design influence, materials used, and emphasis on craftsmanship, the British reserve prevented the

Figure 8. Knox designed this gold "waist clasp" for Liberty and Co. (c. 1901). Created as a monogram E.R. (Edward Rex) in honor of King Edward VII, it well exemplifies the whiplash line. Courtesy of the Jesse \& Laski Gallery, London.

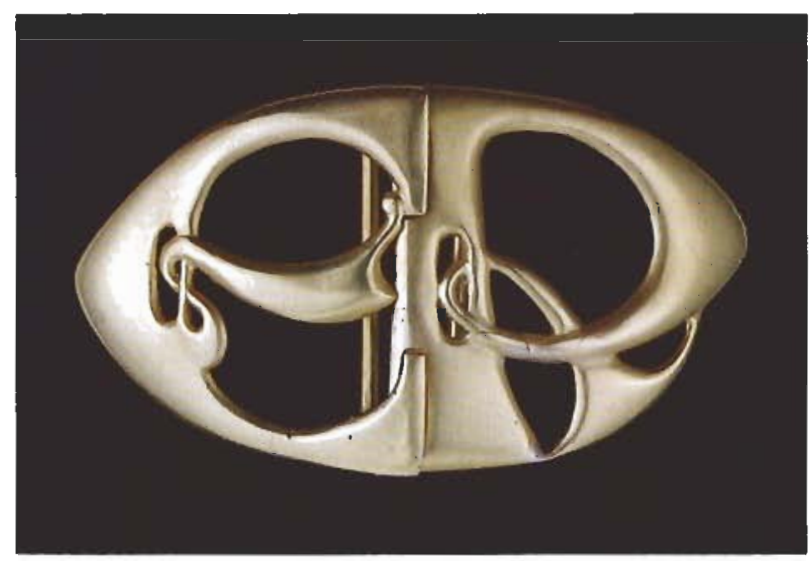

total indulgence in Art Nouveau that ultimately gave it such great impact. The greater freedom of artistic expression in France enabled the French to develop the basic concepts embodied in the Arts and Crafts movement in England into the full sensuality, lyricism, and fancifulness seen in works by Lalique and others.

\section{FRANCE}

French Art Nouveau jewelry is generally considered to represent the style in its purest form. For innovation, imagination, quality of workmanship, and mastery of techniques, the French Art Nouveau designers are unsurpassed.

French jewelers were inspired by gothic and rococo designs as well as by design concepts recently introduced from Japan. There is also some evidence that the avant-garde of the Parisian cafe society had been experimenting with drugs for some time in their ongoing search for new experiences and new sources of inspiration (Armstrong, 1977). This experimentation may have contributed to some of the bizarre combinations of insects, animals, and humans that are frequently seen in French Art Nouveau jewelry: women's serene faces emerging from monsters' jaws, winged sea serpents, or the baleful glare of a Medusa's head writhing with snakes.

Through the theater and the artistic salons, the "emancipated" women of the 1880s and '90s also acted as inspiration to the artists of the day. Sarah Bernhardt, whose flamboyant stage performances took Paris by storm, commissioned bold jewelry for the stage. Loïe Fuller danced with diaphanous veils. And Cléo de Mérode let her hair flow loose while she danced.

Dozens of French jewelers designed in the Art Nouveau style, but the one who contributed the most overall in terms of innovative design and use of materials was René Lalique.

René Lalique. Lalique was born in 1860 in Ay on the river Marne. He was apprenticed at 16 to Parisian jeweler Louis Aucoc, from whom he learned the traditional jewelry-making techniques. After two years with Aucoc, he went to England and studied at Sydenham College. In 1880, he returned to Paris and for the next five years worked as a designer of jewelry, fans, fabric, and wallpaper. He established his own business in 1885, and was subsequently commissioned by Sarah Bernhardt to make some jewels for the stage. 
In 1895, Siegfried Bing converted his Japanese import shop into a store that featured art, textiles, jewelry, glass, and furniture in the new style. He named it La Maison de l'Art Nouveau, thus giving the movement its name and serving to bring prominent artists of the time into the public eye. Among these were Lautrec, Bonnard, Mucha, Tiffany, Mackintosh, Beardsley, and Lalique. Also at this time, Lalique submitted jewels to a competition at the Salon de la Société des Artistes Français. One of these, a cloakclasp, was "arguably the first Art Nouveau jewel to use a naked female" (Becker, 1985). Critics raved about his work, especially praising his unusual style and technique, which promised to rejuvenate the art of jewelry making.

Lalique reached the pinnacle of his success at the 1900 Paris Exhibition. Lalique's pavilion, designed entirely by himself, had soft gray carpets and gray gauze drapes against which hung black velvet bats. The front was framed with a wrought iron grille depicting partially clothed winged women. The pavilion served as a perfect showcase for his jewels, which were displayed in cases on white watered silk and ground glass. His exhibit caused an immediate sensation, and for it Lalique won a grand prize and the rosette of the Legion of Honor. After that, Lalique was inundated with international commissions. His largest came from the Armenian banker, Calouste Gulbenkian, for whom Lalique produced a series of 145 pieces from 1895 to 1912 . These jewels, perhaps Lalique's most fantastic and unusual pieces, can be seen today at the Gulbenkian Museum in Portugal. Unfortunately, the price of fame for Lalique was to see his work endlessly copied and imitated. This plagiarism and cheap commercialization disillusioned Lalique, and once the commission to Gulbenkian was completed, he ceased making jewelry and turned all of his talent to glassmaking (Becker, 1985).

Lalique's pieces overall are dramatic and theatrical, with motifs drawn from nature that are full of an underlying sexual tension. His women are beautiful, sensual, flowing nudes that are often fantasy creatures with wings or tails, part insect or fish. Lalique was innovative in his use of materials and is credited with being the first to use the material horn in his jewels. Over the years; he produced many brooches, combs, pendants and tiaras of horn, which he carved, stained, enameled, and polished, often studding the pieces with gold

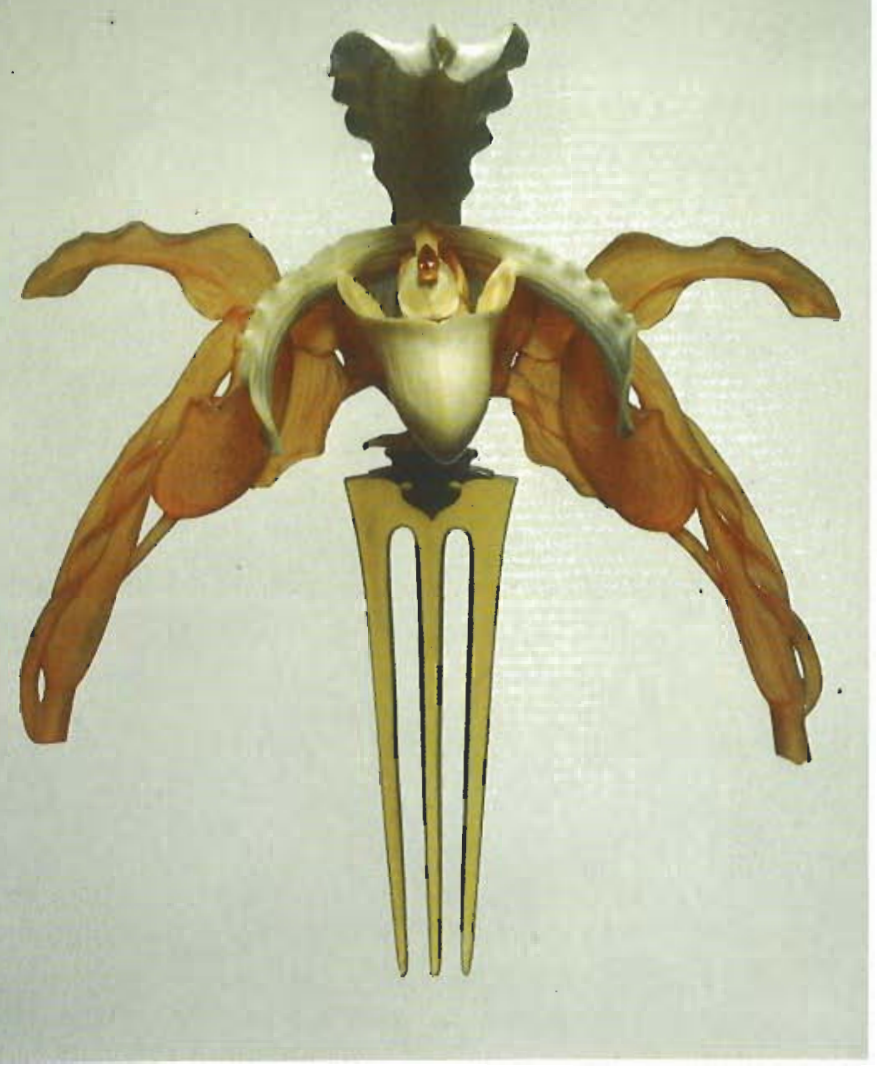

Figure 9. René Lalique is credited with being the first Art Nouveau jeweler to use horn as a material in jewelry. This orchid diadem (14.5 $\times 16.0 \mathrm{~cm}$, c. 1903) also includes ivory, topaz, and gold. Courtesy of the Calouste Gulbenkian Museum. From the Lalique exhibit organized by the International Exhibitions Foundation, Washington, DC.

and gemstones (figure 9). Much of his work incorporates glass, either in one of the enameling techniques that were being experimented with at that time, or as pâte-de-verre. This "glass paste" could be given a matte or shiny surface, ideal for faces, flowers, or other figures. Lalique was also fond of opals and moonstones (figure 10). Many of his pieces use faceted moonstones with diamonds to create a subtle play of sheen and sparkle. Opals were used as symbolic water accents or as eyes in a peacock's tail (figure 11). In some cases, Lalique used large slices of opal as a background for intricately chased and enameled gold.

Lalique was a primary force in Art Nouveau jewelry. His jewels are without equal for originality, technique, and integration of materials, and they served as a beacon for other jewelers to follow. Although literally hundreds of other French jewelers and craftsmen manufactured Art Nouveau jewels, many produced but a single piece, so that 


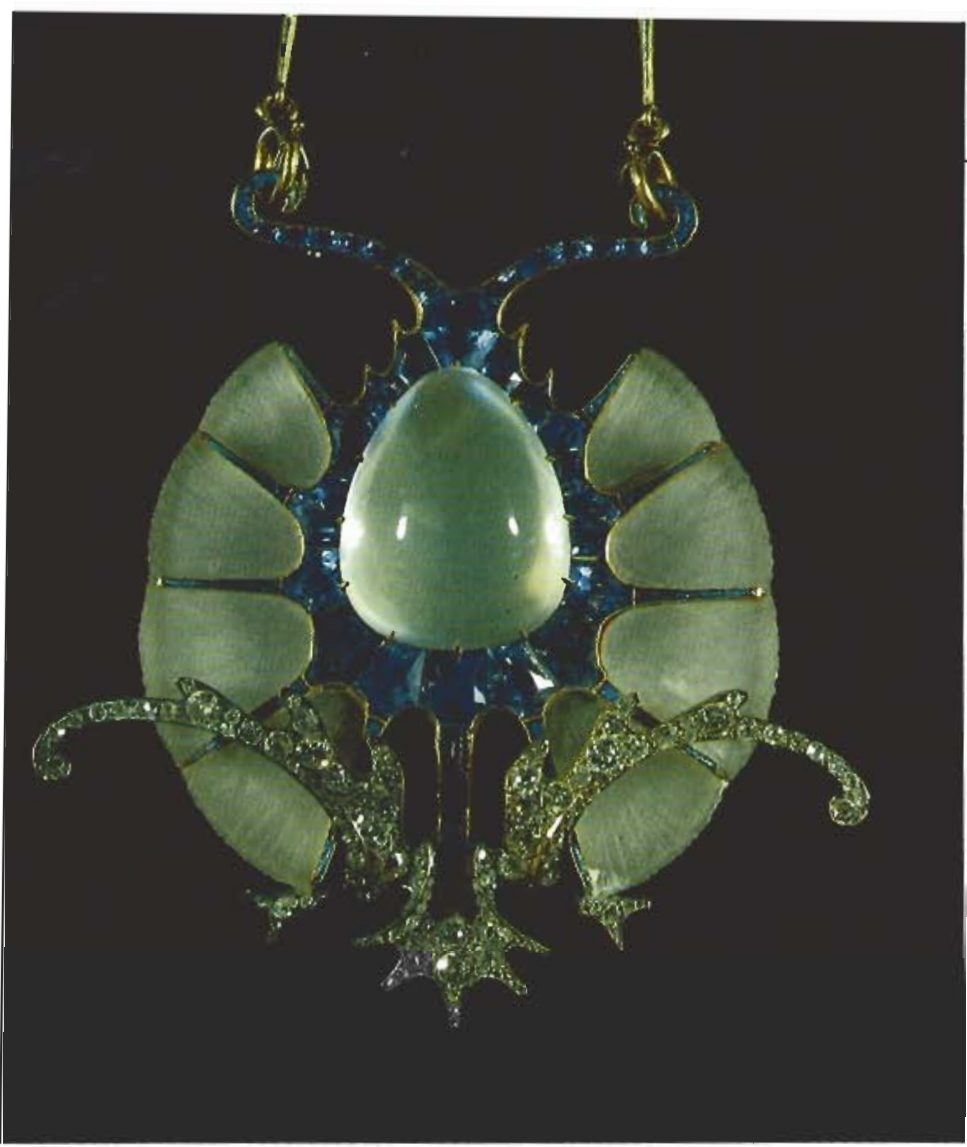

Figure 10. This flower thistle pendant of enameled gold, moonstone, sapphires, and pâtede-verre shows how adept Lalique was at mixing his materials. The piece, which measures $8.4 \times 8.2 \mathrm{~cm}$ and is dated at c. 1900 , is from the Lalique Exhibit organized by the International Exhibitions Foundation, Washington, DC. Courtesy of the Calouste Gulbenkian Museum.
Lalique's great volume of works is all the more astonishing.

Henri Vever. The grandfather of Henri Vever (1854-1942) founded the Maison Vever, a leading Parisian jewelry firm. Henri and his brother Paul took over the firm in 1881, and made innovative changes in the design and manufacture of their jewelry. Like Lalique, Henri Vever also won a grand prize at the 1900 Paris Exhibition. His firm commissioned designers such as Eugene Grasset and Etienne Tourette. Vever was unusual as an Art Nouveau jeweler in that he continued to use rubies, emeralds, sapphires, and diamonds in profusion rather than the less expensive gems and materials favored by Lalique and others. The firm of Vever was also known for their haircombs of horn in organic motifs with plique-à-jour enamels and freshwater pearls. Vever's work, however, generally showed more reserve than Lalique's (figure 12), possibly because Vever catered to a more conservative clientele (Battersby, 1968). Henri Vever was also a prolific writer and critic of Art Nouveau; his three-volume work on 19th-century jewelry, La Bijouterie Française au XIX Siècle (1906-1908), contains much information about the leading Art Nouveau jewelers.

Georges Fouquet. In the 1880s, another Parisian firm, Fouquet, also began to use Art Nouveau

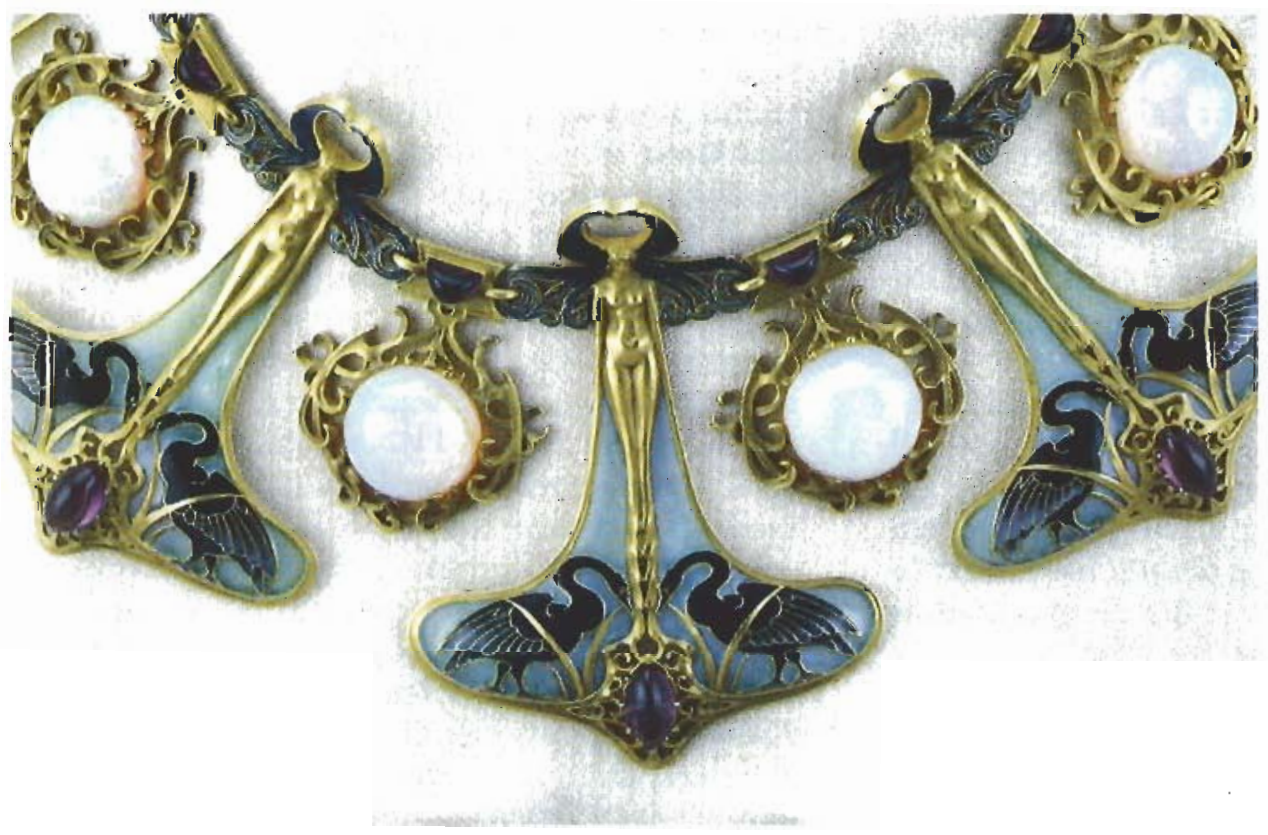

Figure 11. Opals were frequently used in Art Nouveau jewels. This female figure and swan necklace by René Lalique incorporates black enameled gold, opals, amethysts, and plique-àjour (c. 1899). Courtesy of Lillian Nassau and the Metropolitan Museum of Art. From the Lalique Exhibit organized by the International Exhibitions Foundation, Washington, DC. 
motifs, but the jewelry was stiff and lacked the movement and grace usually associated with the Parisian style. In 1895, Georges Fouquet (18621957), son of the founder, took over the firm and made major changes. Collaborating with Desrosiers, an independent designer, Georges Fouquet produced some very fine pieces, primarily in gold with enamel and gemstones. Much of his work is characterized by lines of diamonds or other gemstones placed along curves for emphasis (figure 13). In later pieces, tiny flakes of gold and colored foil were added to his translucent enamels to give an extra sheen.

Fouquet also employed Alphonse Mucha (1860-1939), the celebrated poster artist, to design jewelry specifically for the 1900 Paris Exhibition. Their first collaborative project was the snake ringbracelet executed as a commission for Sarah Bernhardt to wear on stage. This elaborate piece is noted especially for its opal inlay. The partnership of Fouquet and Mucha, which lasted only two years, produced dramatic, strange, largely unwearable pieces, suggestive of ancient Byzantium. Characterized by clusters of gem pendants dangling asymmetrically from fantastic diadems and necklaces, Mucha's designs for jewelry are beautiful on paper but impractical for general wear.

Fouquet continued to work in Art Nouveau motifs, however, manufacturing Desrosiers's more feasible designs, until around 1908. After this, he "lapsed into a more subdued semi-abstract Edwardian style, leaving naturalistic excesses behind him" (Becker, 1985).

Other French Art Nouveau Jewelry Designers. Several other large French jewelry houses also produced jewels in Art Nouveau style. Boucheron made sculptured pieces of chased, enameled gold set with gems and pâte-de-verre. A gold belt buckle with two lionesses biting into a carnelian above a green pâte-de-verre lion's head exemplifies Boucheron's style. Chaumet also expanded his style to include Art Nouveau jewels, although few of his pieces exist today. Once the fashion was over, most of these Nouveau jewels were disassembled and their precious components reused (Becker, 1985). Cartier produced a few pieces but only as commissions. They were mostly symmetrical, stiff renditions of popular plant motifs, using gold, plique-à-jour, and precious stones. Cartier primarily catered to the Edwardian taste for elaborate monochromatic jewels.

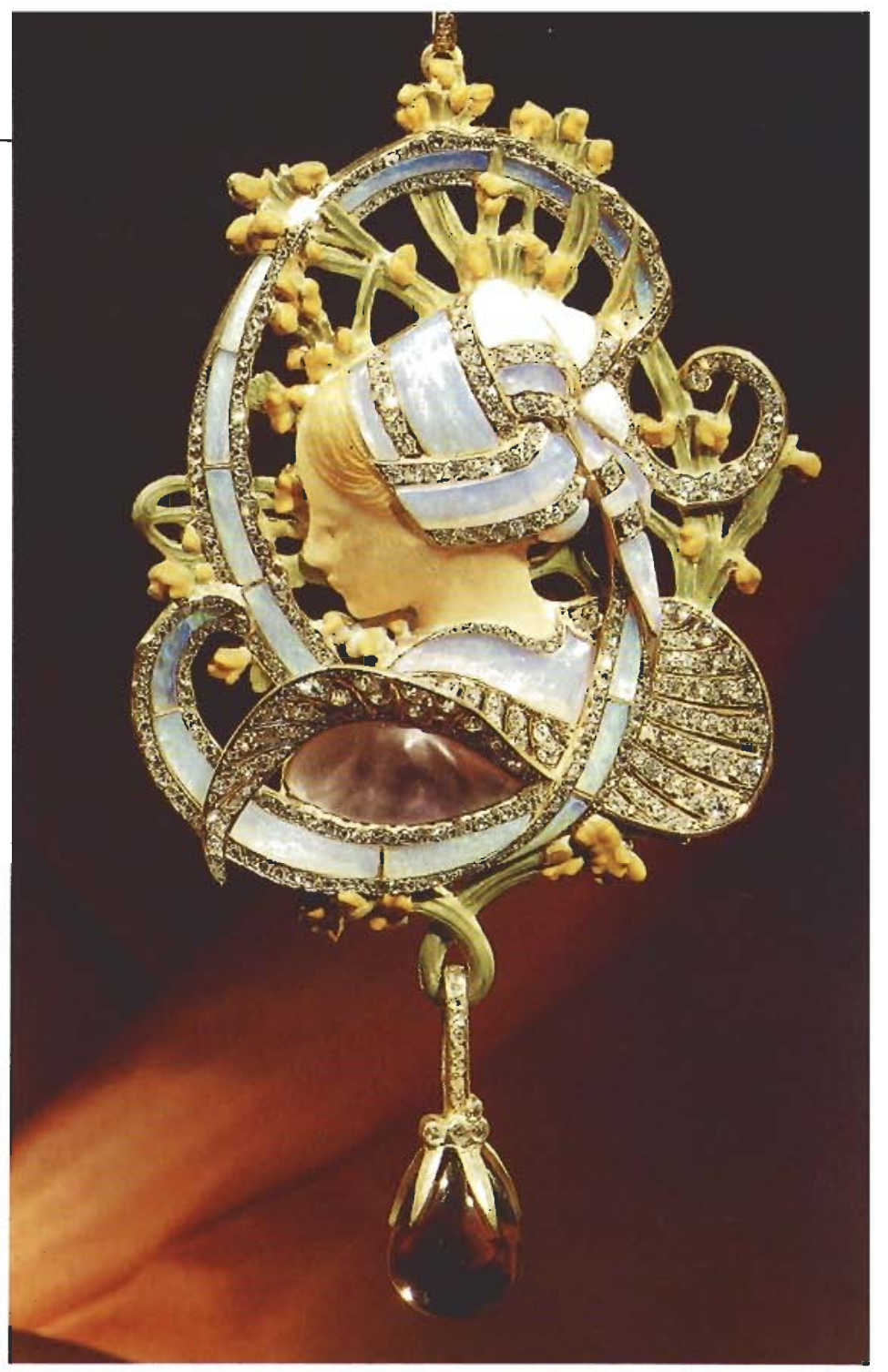

Figure 12. Henri Vever designed this "Bretonne" pendant of enameled gold, inlaid opal, amethyst, and diamonds for the 1900 Paris Exhibition. Private collection.

\section{GERMANY}

In Germany, the new style was called Jugendstil after the new arts magazine Jugend (youth), which promoted the latest trends. Jugendstil was manifested in two distinct versions. The first version, popular prior to 1900 , was influenced by naturalism, Japanese art, and the English floral style. In this version, German jewelers also imitated French jewelry with an adeptness that made it difficult to distinguish German pieces from those of French origin. These were principally produced in the town of Pforzheim, which has been largely devoted to the manufacture of jewelry since the 16th century.

One of the most interesting designers of this particular version of German Art Nouveau jewelry 


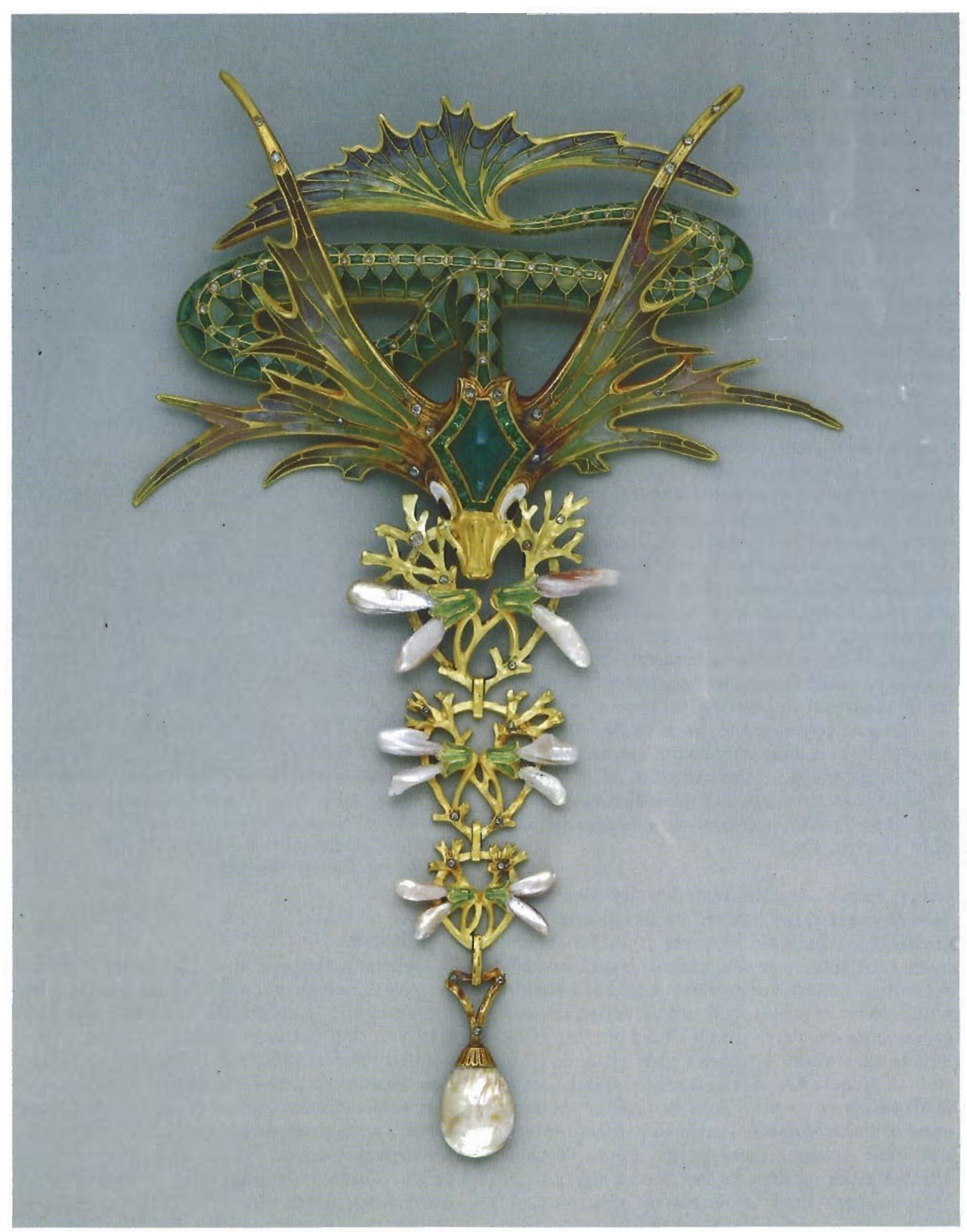

Figure 13. Note the use of gems to outline and highlight this sea serpent corsage ornament fabricated by Georges Fouquet using enameled gold, plique-à-jour, emeralds, and diamonds with freshwater and saltwater pearls (c. 1902). Private collection. 


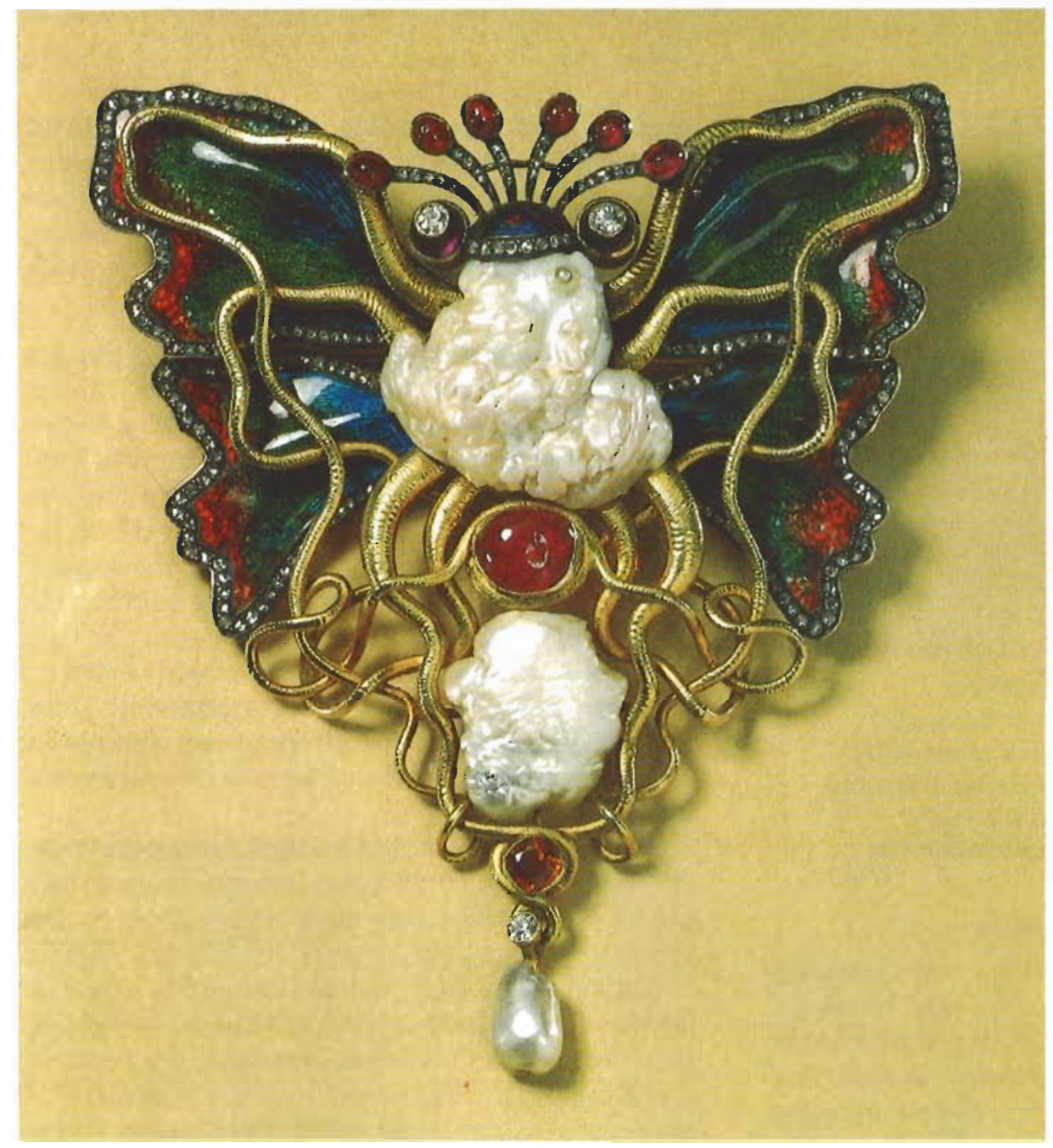

Figure 14. This brooch of enameled gold, baroque pearls, diamonds, rubies, amethysts, and topaz shows the French influence on early German Art Nouveau jewels. Named "Tintenfisch und Schmetterling" (Octopus and Butterfly), it was designed by Wilhelm Lucas von Cranach and executed by Louis Werner for the 1900 Paris Exhibition. Courtesy of the Schmuckmuseum, Pforzheim, Germany.

was Wilhelm Lucas von Cranach (1861-1918). He left his occupation as a forester and came to Berlin as a portrait and landscape painter in 1893. Soon thereafter, he began to design jewels, which were manufactured in Berlin by Louis Werner and ultimately displayed at the 1900 Paris Exhibition. Von Cranach's designs are influenced both by his understanding of nature and by a gothic fascination with mythic beasts. His most famous piece, "Tintenfisch und Schmetterling," is of an octopus with butterfly wings (figure 14).

The second version of Jugendstil was a softened, geometric style that developed out of the Darmstadt colony, which was founded in 1897 under the patronage of the Grand Duke Ludwig of Hesse. As the grandson of Queen Victoria, the Grand Duke made frequent trips to England, where he became familiar with the Arts and Crafts movement and William Morris. It was his dream to form an ideal environment for artists and artisans to develop their crafts. He realized this aspiration by commissioning the Austrian architect Joseph Maria Olbrich (1867-1908) to organize and design the buildings for the colony. In 1899, the colony was officially opened and young designers, architects, artists, and artisans from all over the world came to join it under the direction of Olbrich. Jewelry designs from the colony were submitted to Theodor Fahrner (1868-1929), a Pforzheim jeweler, who did the actual manufacturing. The pieces themselves were made of silver with enamelwork and cabochon opals, agates, and mother-of-pearl, following the principle of making artistic jewelry available to all social classes (figure 15). This fashionable, affordable jewelry brought the colony into the public eye, and the new designs helped to change Jugendstil from the earlier flowery, representational motifs to the abstract, biomorphic style that ultimately led to the development of Art Deco in the 1920s and '30s. 


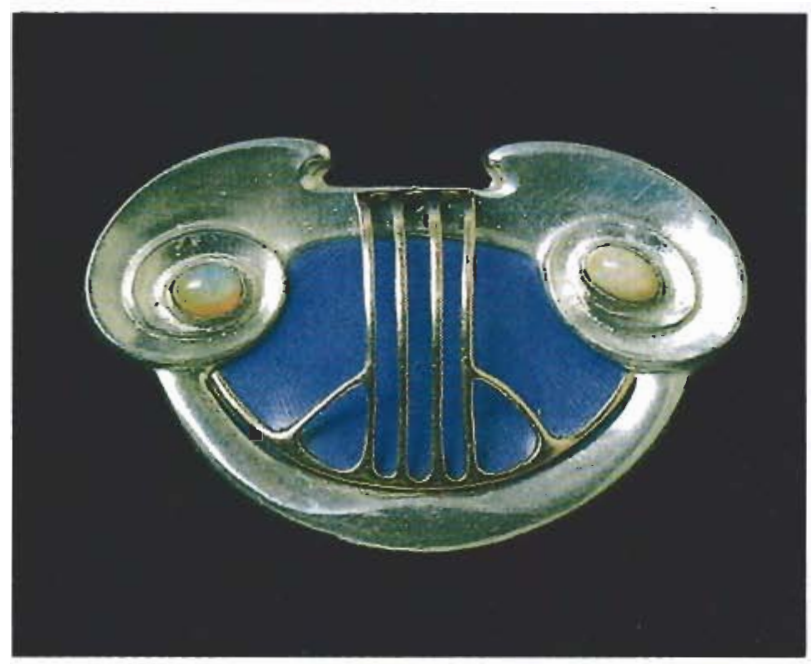

Figure 15. Theodor Fahrner executed the jewelry designs of many prominent German artists. This silver brooch is a good example of the softened geometrics and affordable materials that popularized lugendstil jewels (c. 1902). Courtesy of the Tesse «) Laski Gallery, London.

\section{OTHER EUROPEAN DESIGNERS}

Spain. Although England, France, and Germany had the greatest impact on the Art Nouveau movement in jewelry, other countries in Europe also produced important designers. Spain's Art Nouveau movement was largely confined to architecture; yet one jeweler in particular, Luis Masriera (1872-1958), made significant pieces in the Art Nouveau style. After viewing Lalique's work at the 1900 Paris Exhibition, Masriera returned to Barcelona and closed his shop for six months, during which time he melted down his entire stock of traditional jewels and feverishly designed and manufactured jewelry in the Nouveau style. When he reopened his shop, the display of his jewels caused such a sensation that his entire new stock was sold out within a week. Masriera's adaptations of French Nouveau jewelry frequently incorporated winged nymphs with flowers in their hair, emerging from gem-set frames or borders (again, see figure 1). The female figures often have plique-à-jour enameled wings, and the borders of their draped clothing are occasionally set with diamonds. Although these figures are lithe and free, they are fully clothed and quite chaste, perhaps out of respect for Spain's conservative religious principles. Some of them represent religious icons of angels or the Virgin Mary surrounded by jeweled halos. One of Masriera's most distinctive jewels is a pendant portraying the medieval heroine, Isolde, in a jeweled crown against a plique-à-jour gothic window (see cover). This was undoubtedly inspired by the Wagnerian opera Tristan and Isolde, which was enjoying enormous popularity in Europe at that time (Becker, 1985).

Belgium. Belgium played a leading role in the Art Nouveau movement in architecture and interior design. The Belgian designers provided a buffer between the flamboyant French and reserved English styles, serving to integrate and meld the two extremes. Henry Van de Velde (1863-1957), architect and designer, worked to integrate the applied arts so that they harmonized with one another. He turned to jewelry as yet another outlet for this expression. His jewelry was abstract with a strong, pseudomorphic line that was suggestive of plant growth. Van de Velde's work was most admired in Germany, which motivated him to live and work there after 1899.

Philippe Wolfers (1858-1929), Belgium's most distinctive jewelry designer, worked more in the literal French Nouveau style rather than in the abstract interpretation seen in Van de Velde's works. Wolfers's work is eerie and highly original. He was trained as a jeweler by the family firm in the 19th-century tradition, learning all aspects of jewelry malking. Impressed by the exhibitions of Japanese art that inundated Europe in the 1870s, Wolfers changed his jewelry designs from stiff, fussy ornaments to sweeping, realistic portrayals of nature.

When the first ivory tusks arrived from the Belgian Congo in 1892, Wolfers began carving ivory in flower forms which he introduced at the International Exhibition at Antwerp in 1894. He also used carnelian, opal, and tourmaline, skillfully carved by his artisans into flowers or animals.

Wolfers's jewels are haunting and unusual, producing some of the same shock effect as Lalique's. He contrasts soft, sensuous forms with bizarre and harsh figures (figure 16). From 1897 to 1905 he produced a series of 109 Art Nouveau jewels, each of which was titled and had a plant, insect, or animal motif. After 1910, as Art Nouveau waned, Wolfers became more of a sculptor, eventually ceasing to make jewelry altogether.

Austria. In Austria, as in Germany, artists felt stifled by the historicism that had dominated art and architecture in the first half of the 19th century and yearned to express themselves in a 


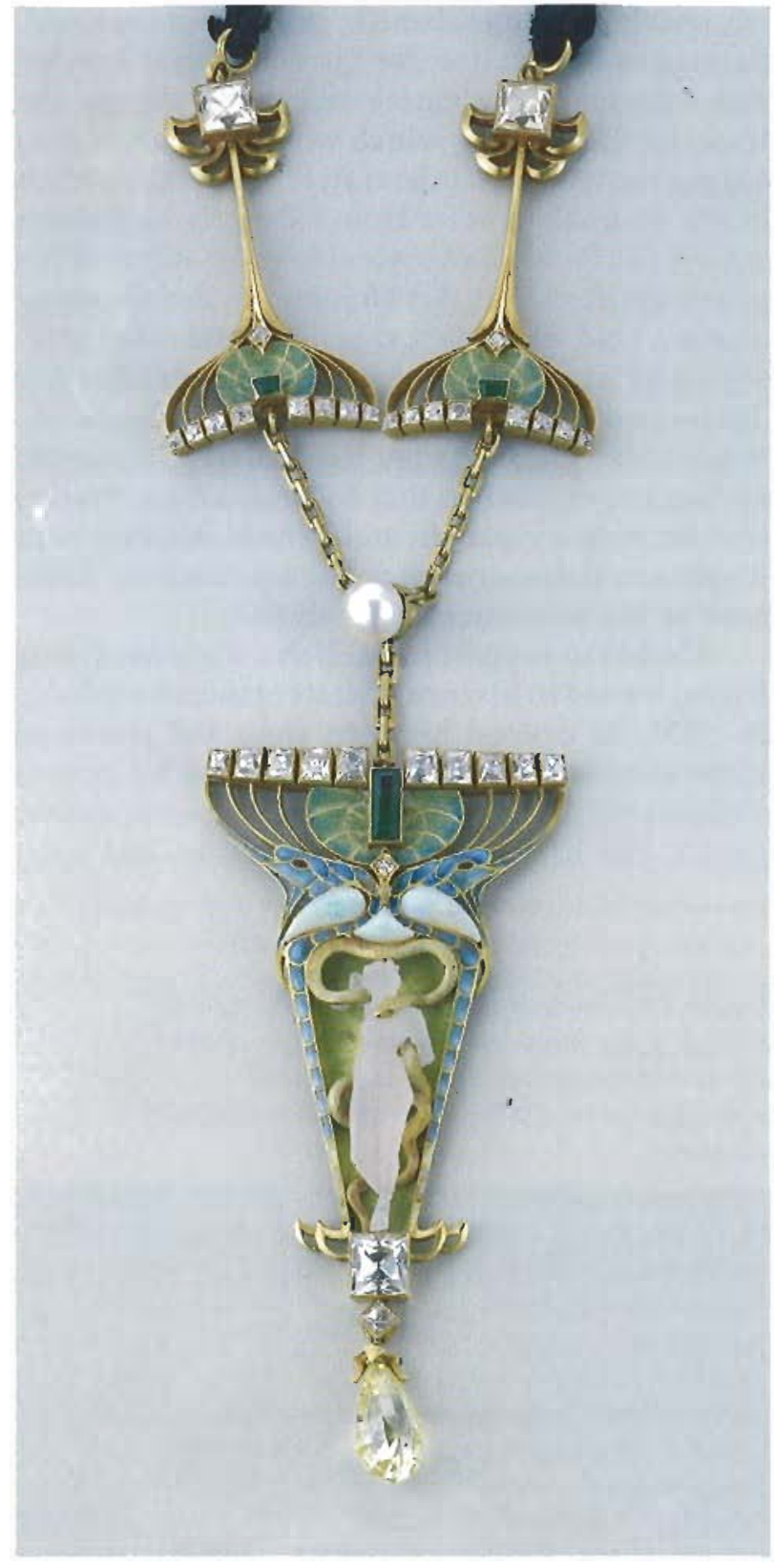

Figure 16. This Eve and serpent pendant was fashioned from gold, carved rose quartz, opals, enamel, pearl, and diamonds, with a fancy yellow diamond drop, by Philippe Wolfers. The piece, manufactured c. 1905, measures $7.5 \times$ $13.5 \mathrm{~cm}$. Courtesy of Lillian Nassau.

streamlined, updated fashion. In 1897, a group of artists broke away from the traditional teaching of the Vienna Academy and formed their own group, calling it the Vienna Secession. Austria, like Germany, was also influenced by the Arts and Crafts movement in Great Britain and particularly by Mackintosh's Glasgow School (Waddell, 1977). By the mid-1890s, the Vienna Secession began to manifest a cubic, rectilinear form of design in art and architecture that was to become their hallmark style. Until the early 1900s, Art Nouveau jewelry in Austria was still modeled after the naturalistic French style, offering the ubiquitous dragonflies, butterflies, and women with swirling tresses. After 1900, a founding member of the Secessionists, Josef Hoffman (1870-1956), formed the Wiener Werkstatte (Viennese Workshop) with Koloman Moser (1868-1918). They patterned their workshop after the guilds that were prevalent in England, with one major difference: Where the British guild members were primarily artists that had no training in the jewelry arts, the members of the Wiener Werkstatte were formally trained artisans, highly skilled in the decorative arts.

Hoffman's jewelry designs were fabricated by the artisans at the Wiener Werkstatte under his close supervision. Because of his admiration for the work of the Scottish craftsman Charles R. Mackintosh, Hoffman's designs reflect the same ultra-stylized flowers and leaves, joined by long, gently curving lines, of the Glasgow School. Hoffman made his jewelry in silver (figure 17) or goldplated silver set with cabochon agates, malachite,

Figure 17. A gold-plated silver brooch fabricated by the Wiener Werkstatte from a design by losef Hoffman shows the influence of the Glasgow School (c. 1910). Courtesy of the Schmuckmuseum, Pforzheim, Germany.

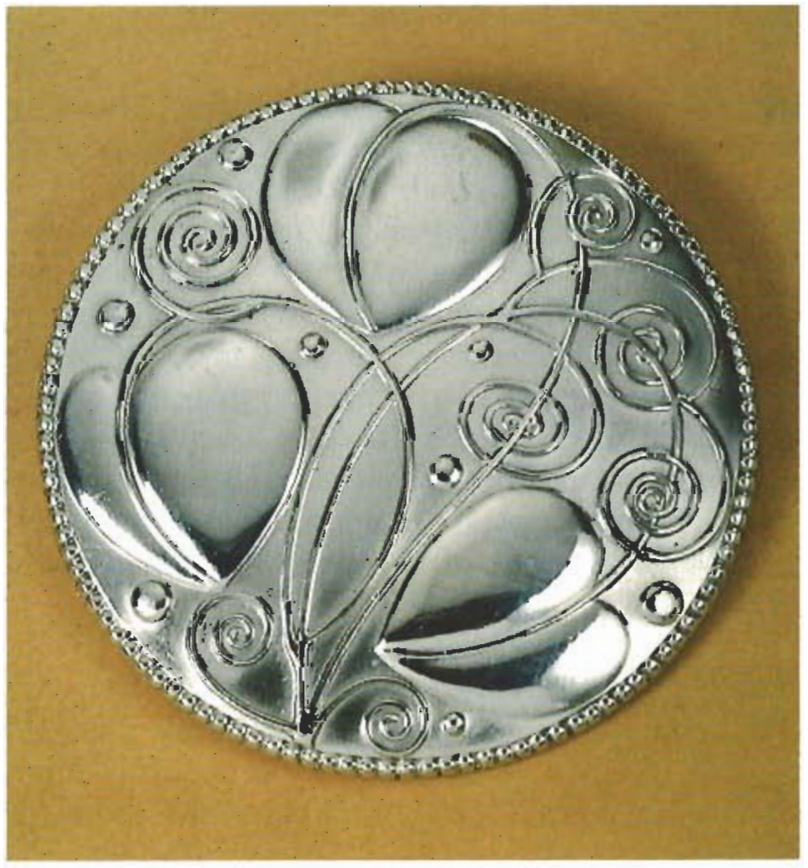


His inspiration came from the Lalique exhibit at the 1900 Paris Exhibition, coupled with his own interpretation of Viking motifs and a childhood love of nature (figure 19). Jensen's pseudomorphic shapes and curvilinear designs were rooted in Art Nouveau, but his work transcended the period. It gained in popularity as his style evolved into a streamlined version of Art Nouveau, which was more in keeping with the trends of the 1920s and '30s (Lassen, 1980).

\section{UNITED STATES}

A dramatic shift occurred in jewelry making in the United States when the U.S. government assigned a duty on imported jewelry in 1850 . With the imposition of the duty, to protect the metalsmiths, jewelry centers arose quickly and a distinctive American style began to emerge. Two major developments characterize the new-art movement in America: the role of Louis Comfort Tiffany in glass and jewelry, and the rise of the Arts and Crafts movement in Chicago.

Tiffany. The three most popular exhibits at the 1893 World's Columbian Exposition in Chicago were the Japanese, the British Arts and Crafts, and the work by the Tiffanys - the famous Tiffany and Company of New York and Louis C. Tiffany's Glass and Decorating Company. Together, the two Tiffany firms won 55 awards.

Louis Comfort Tiffany (1848-1933) was born into the well-established jewelry firm, Tiffany and Co., that his father Charles Lewis had founded. Apparently, it was clear early on that Louis would be an artist and not the businessman his father had been. After studying in Paris for two years, he visited Spain and North Africa, in the course of his travels, he acquired a taste for Oriental and Moorish art.

While Louis was traveling, his father hired George Frederick Kunz as Tiffany's first gemologist in 1877. The elder Tiffany encouraged Kunz to travel throughout the world to add not only diamonds but also colored stones to the store's inventory. As Kunz describes his activities at Tiffany, "In those first days, very naturally a large part of my interest was engaged in this problem of discovering and introducing one after another these lovely semiprecious stones in which no jewelers of the time were even slightly interested. I remember once showing some of these gems to [noted writer] Oscar Wilde, who was himself a connoisseur and

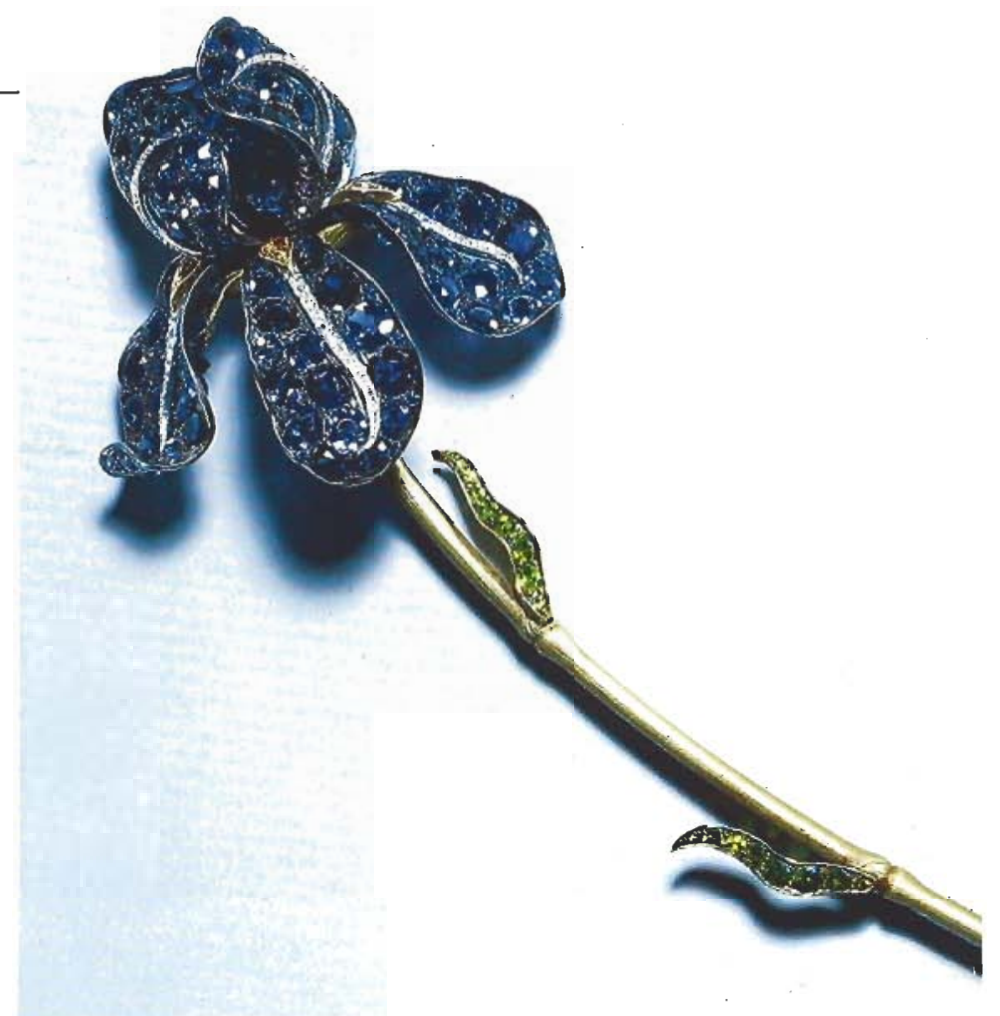

Figure 20. This iris corsage ornament of gold, sapphires (from Montana), diamonds, demantoid garnets, and topaz was shown in the Tiffany pavilion at the 1900 Paris Exhibition. Courtesy of the Walters Art Gallery, Baltimore.

had a not uninteresting collection of his own. Oscar Wilde said 'My dear fellow, I see a renaissance of art, a new vogue in jewelry in this idea of yours. Bah! who cares for the conservatives! Give them their costly jewels and conventional settings. Let me have these broken lights - these harmonies and dissonances of color" " (Kunz, 1927).

But no matter where he traveled or what gemstones he bought, Kunz never forgot his first enthusiasm for America's "semiprecious stones" (Purtell, 1971), especially the matrix turquoise, tourmalines, peridots, freshwater pearls, and newly discovered sapphires from Montana. Kunz organized a collection of American gemstones for the Tiffany exhibit at the Paris Exhibition of 1889. This undoubtedly had a major impact on the newart designers and jewelers because it showed them a whole new world of colored stones. His second major exhibit, composed of gemstones from around the world, won him a grand prize at the 1900 Paris Exhibition (figure 20).

In 1889, Louis Tiffany began a close business association with Siegfried Bing, who became his agent in Paris. That same year, Tiffany was also made director of design at Tiffany and Co. In the 


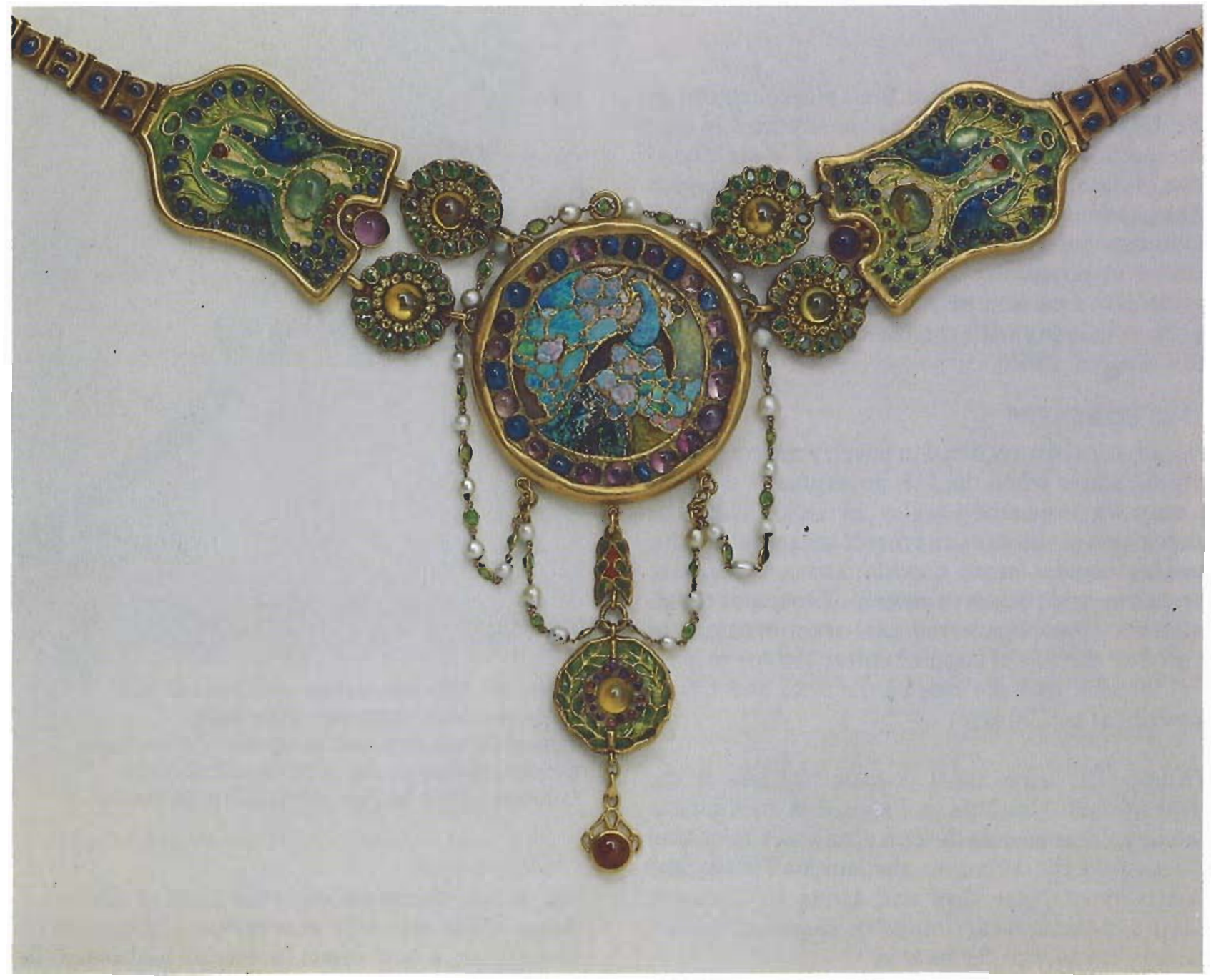

Figure 21. This Peacock necklace (c. 1906) was designed by Louis C. Tiffany and manufactured by Julia Munson Sherman. It contains opals, amethysts, sapphires, demantoids, rubies, and emeralds. The reverse side is exquisite cloisonne enamel on gold. From The "Lost" Treasures of Louis Comfort Tiffany, by Hugh McKean. Copyright (c) 1980 by Hugh McKean. Published by Doubleday \&) Co., Inc.

Tiffany and Co. studio, he worked on designs that included "art" jewelry, now known as Tiffany Studio jewelry. There, he could draw on the storehouse of colored stones acquired by Kunz. According to Sataloff (1984), Louis Tiffany "used every stone to its greatest advantage, just as he had combined colors of glass to their advantage." Not only was his goldwork sinuous and fluid, but he also made great use of baroque pearls and unusual colored stones such as demantoid garnet, turquoise (he even convinced Tiffany and Co. to buy a mine in Arizonal, lapis lazuli, and opal.

Julia Munson Sherman was responsible for the production of Tiffany Studio's jewelry. An admirer of William Morris, she had studied the Arts and Crafts workers in England. Working in ceramics, metal, and enamels at the Tiffany Studio, Julia Munson Sherman was the one who developed the techniques for the enamels Tiffany used in jewelry. In 1903 she became head of the Tiffany and Co. jewelry department, where she executed Louis Tiffany's jewelry designs. Because she did not sign any of the pieces, her key role at Tiffany's has only recently become known (Novas, 1983).

Tiffany's pieces have been aptly described as "an unusual mixture of handwrought Arts and Crafts and the organic motifs of Art Nouveau, with an emphasis on unusual materials chosen for colour and effect rather than intrinsic value ... he drew on his favorite Oriental and Byzantine motifs and was dedicated to fine workmanship in all aspects of his jewelry" (Becker, 1985). An example 
is the Peacock necklace shown at St. Louis in 1904 and the Paris Salon of 1906 (figure 21).

Another leading New York firm, Marcus and Company, produced Art Nouveau jewelry characterized by enamels in vibrant colors such as bluegreen, dark green, and deep pink that were used to compliment gemstones. Although the use of strong colors gave the Marcus and Co. pieces a distinctive character (figure 22), this jewelry also borrowed motifs from the French floral Art Nouveau and sometimes included coils of metalwork or a soft curving gold line.

Arts and Crafts Movement in Chicago. Chicago was the most receptive of American cities to the reforming principles of the British Arts and Crafts movement because it coincided with cultural and social reforms already under way. Several prominent British exponents of the Arts and Crafts movement, such as Ashbee, visited Chicago and lectured at the Chicago Art Institute.

The Chicago Arts and Crafts Society was founded in 1897. The society's creative use of natural materials and simplifications of line and ornament embodied the Arts and Crafts movement. At the beginning of the new century, Chicago could claim a school of metalsmiths working within the Arts and Crafts traditions using simple forms and natural materials. While they adhered to the principle that the metal must be worked by hand, it was not considered improper to use machines to eliminate some of the drudgery, such as flattening the metal into sheets. For inspiration, the Chicago metalsmiths turned to American Indians, the American colonial period, or nature. Just as in England, common garden flowers were popular motifs. The jewelry produced by these metalworkers ranged from bold to delicate and reflected the sensual lines and floral motifs of French Art Nouveau as well as the peacock motif and mechanical lines associated with British Arts and Crafts. Moonstones, amethysts, baroque pearls, aquamarines, and opals were the choices for stones. Enameling and acid etching of the metal were also popular (Darling, 1977).

Jewelry making particularly appealed to the growing number of women who were trying their hand at metalsmithing. In Chicago, the first workshops involved in metalsmithing were established by women. Clara Barck Welles (1868-1965) opened one, the Kalo Shop, in September 1900. The Kalo motto- "Beautiful, Useful, and Enduring"seemed to echo William Morris's adage "have nothing to your houses which you do not know to be useful, or believe to be beautiful" (Darling, 1977). The Kalo Shop specialized in silver jewelry set with pearls, moonstones, topazes, or carnelian, as well as in silver objects from bowls to tea sets.

The demand for handmade metal became so great that Marshall Field \& Company created a fully equipped craft shop and metal foundry to augment the jewelry workroom it created in 1904 on the tenth floor of the State Street store (Darling, 1977). These operations were quite similar to those

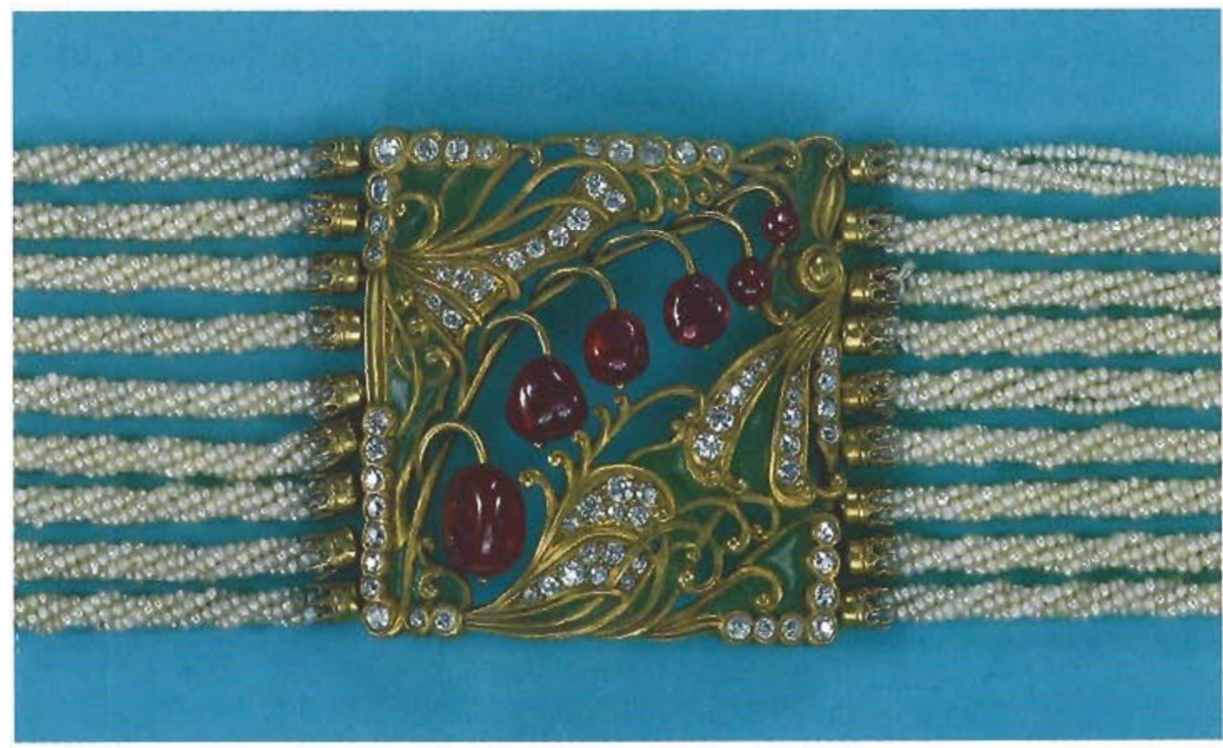

Figure 22. Marcus and Co. created this dog collar of gold, cabochon rubies, diamonds, and plique- $a$ jour enamel with nine twisted seed-pearl ropes (c. 1900). Three of the ruby cabochons are synthetic. Synthetic ruby crystals were on exhibit at the 1900 Paris Exhibition and began to be incorporated into jewelry around that time. Photo courtesy of Christie, Manson and Woods International, Inc 
of Liberty \& Co. in London. Designers and craftsmen produced jewelry that sold under the company name.

Other American Art Nouveau Jewelers. Certainly, there were other American manufacturers and jewelers producing Art Nouveau pieces. Both books by Sataloff and Becker contain in their lists of makers' marks the lesser-known American jewelers. A number of American manufacturers also mass-produced silver jewels in the French Art Nouveau style, notably Unger Brothers, founded in 1878; William B. Kerr and Co. of Newark, New Jersey; Averbeck and Averbeck of New York; and the oldest, the Gorham Corporation of Rhode Island (Becker, 1985).

On the one hand, this mass production of silver Art Nouveau jewelry accomplished a basic tenet of the Arts and Crafts and Art Nouveau movements by creating beautiful objects that working people could afford. However, this same mass production often focused on the superficial qualities of Art Nouveau, ultimately contributing to its decline.

\section{CONCLUSION}

The Art Nouveau movement as a whole was similar to the exotic plant life that much of it depicted. Rooted in the $1880 \mathrm{~s}$, the movement budded in the 1890s, came to glorious flower in 1900 , had faded by 1910 , and was utterly dead by 1915. Over-commercialization of the popular motifs glutted the market and caused Art Nouveau's wane in popularity. The First World War, which devastated Europe from 1914 to 1917, effectively killed the naive romanticism that had given birth to such an ebullient and intensely unique style of artistic expression. Where Art Nouveau had been hailed as an exciting modern trend, it was now damned as "a ludicrous and ephemeral artists' aberration" (Sataloff, 1984). It was as if the public was embarrassed by the emotional excesses that Art Nouveau embodied. Once dead, the movement was buried quickly and without regret. Much of the architecture was demolished, furnishings were replaced, and because they were so representative of the period, women would not wear Art Nouveau jewels once the fashion was over (Klamkin, 1971). After 1914, Art Nouveau gave way to the stark, unemotional geometrics and streamlined stylization of Art Deco.

Although brief, the Art Nouveau movement made a lasting contribution to the applied arts by raising their status in the eyes of the public. Design and construction of buildings, furnishings, jewelry, and textiles were infused with a new level of artistry that has carried through to the present day.

After half a century of disenchantment, the public is again finding beauty in Art Nouveau objects, particularly its jewelry. Artists are adopting some of the motifs and incorporating the Nouveau line into many of their modern designs. A rise in interest can be seen in the number of pieces that have appeared for auction and the popularity of special exhibits such as the one honoring René Lalique that toured the United States in 1986, the "Paris Style 1900, Art Nouveau Bing" exhibit currently touring the U.S., and the upcoming May 1987 exhibit of Lalique jewelry at Goldsmiths Hall, London. These remaining jewels are the embodiment of that ingenuous and exciting time of new beginnings and youthful promise, when all the arts enjoyed an explosion of creativity and artists took themselves to the limits of their imagination and skill.

\section{REFERENCES}

Armstrong N. (1977) Jewellery-An Historical Survey of British Styles and Jewels. Lutterworth, London.

Battersby M. (1968) The World of Art Nouveau. Arlington Books, London.

Becker V. (1985) Art Nouveau Jewelry. E. P. Dutton, New York.

Darling S.S. (1977) Chicago Metalsmiths. Chicago Historical Society, Chicago.

Hinks P. (1983) Twentieth Century British Jewellery. Faber and Faber, London.

Hughes G. (1964) Modern Jewellery. Crown Publishers, New York.

Klamkin C. (1971) The Collectors Book of Art Nouveau. Dodd, Mead and Co., New York.

Kunz G.F. (1927) American travels of a gem collector. Saturday Evening Post, Vol. 200, No. 22, pp. 6-7, 85-86 and 91.
Lassen E. (1980) Georg Jensen. In Georg Jensen, Silversmithy. Smithsonian Institution Press, Washington, D.C.

Nevins D. (1986) Morris, Ruskin, and the English flower garden. Antiques, Vol. 129, No. 6, pp. 1256-1265.

Novas H. (1983) A jewel in his crown. Connoisseur, Vol, 213, No. 860 , pp. 134-140.

Purtell J. (1971) The Tiffany Touch. Random House, New York. Sataloff J. (1984) Art Nouveau Jewelry, Dorrance \& Co., Pennsylvania.

Vever H. (1906-1908) La Bijouterie Française Au XIX Siècle (1800-1900). Paris, H. Floury.

Waddell R. (1977) The Art Nouveau Style. Dover Publications, New York,

Weisberg F. (1986) Art Nouvenu Bing: Paris Style 1900. Harry N. Abrams, New York. 